\title{
MINERAL PREPARATION OF ORES FROM FRIDAY CREEK, KANTISHNA MINING DISTRICT, ALASKA
}

by

Cleland N. Conwell

SPECIAL REPORT 7

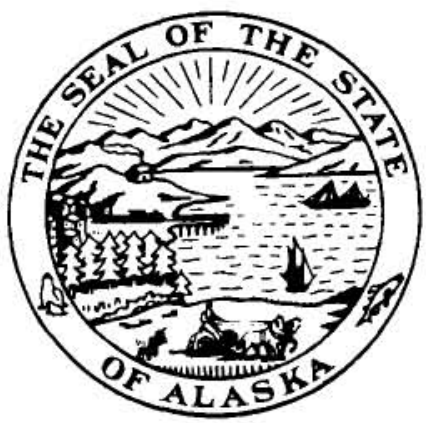

PUBLISHED BY

DIVISION OF GEOLOGICAL \& GEOPHYSICAL SURVEY COLLEGE, ALASKA 1974 
STATE OF ALASKA

William A. Egan, Governor

\section{DEPARTMENT OF NATURAL RESOURCES}

Charles F. Herbert, Commissioner

DIVISION OF GEOLOGICAL \& GEOPHYSICAL SURVEY

Donald C. Hartman, State Geologist 


\section{CONTENTS}

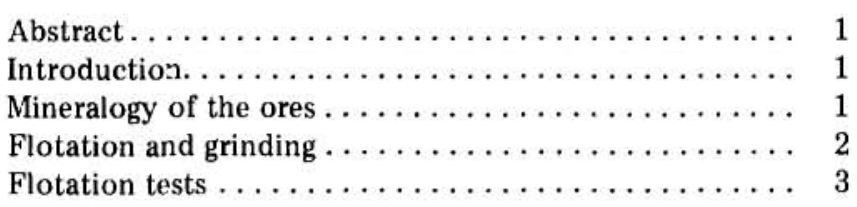

\section{ILLUSTRATIONS}

FIGURE 1. Flow sheet, Alaska Mining and Milling Co. concentrator $\ldots \ldots \ldots \ldots \ldots$

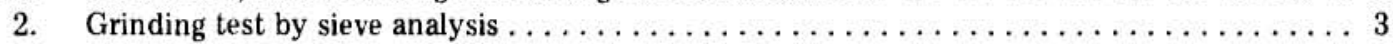

3. Kantishna ore, recovery-reagent curves for sodium isopropyl xanthate $\ldots \ldots \ldots \ldots \ldots$

4. Photomicrographs of Kantishna ore concentrates $\ldots \ldots \ldots \ldots \ldots \ldots \ldots \ldots \ldots \ldots \ldots$

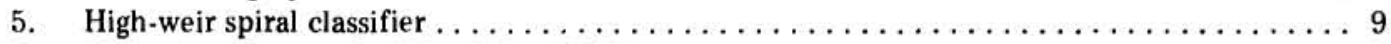

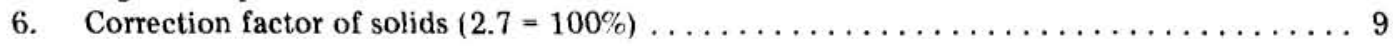

TABLES

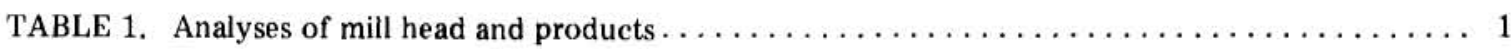

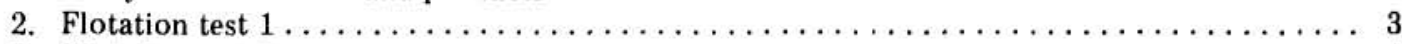

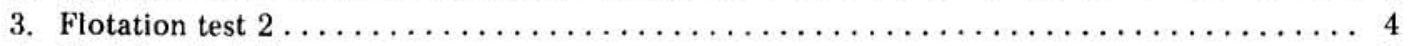

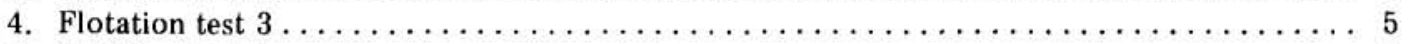

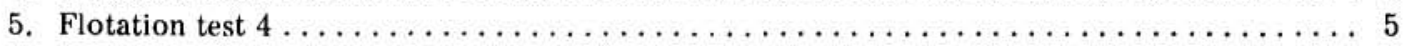

6. Flotation test $5 \ldots \ldots \ldots \ldots \ldots \ldots \ldots \ldots \ldots \ldots \ldots \ldots \ldots \ldots \ldots \ldots \ldots \ldots \ldots$ 


\section{MINERAL PREPARATION OF ORES FROM FRIDAY CREEK, KANTISHNA MINING DISTRICT, ALASKA}

by

Cleland N. Conwell

\begin{abstract}
A complex ore submitted to the Division for study from the Kantishna mining district contains silver, gold, lead, and copper. Although the principal sulphide mineral is pyrite, the principal economic value of the ore is in the silver; the gold appears as metallic "free" gold. Inspection of size fractions indicate sulphides liberate from the gangue at -65 mesh; however, a very find grind, probably -600 mesh, would be required to separate intergrown sulphide minerals. The sulphides liberate from the gangue with a concentration ratio of 2 to 1 . A high-grade lead-silver concentrate was produced containing over $75 \%$ of the silver, with $60 \%$ of the lead to a 9-to-1 concentrate. By regrinding the bulk sulphide concentrate, it was possible to produce a $49.5 \%$ zinc concentrate---low grade, but probably acceptable to a zinc smelter.
\end{abstract}

\section{INTRODUCTION}

Several people provided valuable assistance preparing this report: D.J. Cook of the University of Alaska, who made helpful suggestions and interpretations; D. Grybeck of the University of Alaska, who assisted with polished sections; F.A. Seeton of the Denver Equipment Company, Denver, Colorado, who provided mill-capacity and flotation-cell information; and A.J. Krohan of the American Smelting and Refining Company, Tucson, Arizona, who provided marketing information.

In the summer of 1973 , Glenn Craig constructed a 35-ton/day concentrating mill on Friday Creek near Kantishna, Alaska. Ore processed during the summer season was removed while excavating a 42 -foot shaft and short drift. The ore was not mined selectively and no metallurgical tests were completed prior to construction of the mill.

The intent of this investigation was to separate finegrained galena, sphalerite, and pyrite by selective flotation. In addition, components of the mill were examined to determine if units were properly sized. The test results should aid in future mill tests, in additions or changes in the mill circuit, and in marketing the ore or concentrates.

The apparent theory of mill operation (fig. 1) was to remove coarse sulphides as soon as they were liberated in grinding by placing a jig in closed circuit with the ball mill and classifier. The overflow from the classifier was expected to provide a suitable feed for flotation cells. Material not collected by flotation would be scavenged by the two concentrating tables. Analyses of the average mill heads, the various products, and the tailings from samples submitted by Craig are shown in table 1 .

The analyses indicate a good recovery of the gold but a less-than-satisfactory recovery of silver and lead. There was also poor recovery of zinc, which is a possible benefit because smelters generally allow no payment for zinc in a lead concentrate (and in fact may even assess a penalty). Although the flotation products have the highest silver content, they also contain the highest percentage of zinc. The jig and table products are satisfactory for a lead smelter. If galena (lead) and sphalerite (zinc) were successfully separated in milling, the zinc product could be sold to a zinc smelter, thereby producing additional revenue from the ore.

\section{MINERALOGY OF THE ORES}

The presence of galena, sphalerite, and pyrite, easily identifiable in a hand specimen of the ore, were confirmed

TABLE 1. Analyses of mill head and products

\begin{tabular}{|c|c|c|c|c|c|}
\hline \multirow[b]{3}{*}{ Heads } & \multicolumn{2}{|c|}{ Ounces per ton } & \multicolumn{3}{|c|}{ Weight-percent } \\
\hline & Gold & Silver & Copper & Lead & Zinc \\
\hline & $\overline{0.245}$ & $\overline{35.00}$ & $\overline{0.0985}$ & $\overline{5.90}$ & $\overline{4.80}$ \\
\hline Jig concentrate & 0.960 & 115.20 & 0.2500 & 27.0 & 5.90 \\
\hline Ce.11 feed & 0.160 & 32.09 & 0.0830 & 4.75 & 5.40 \\
\hline Reagent-33 concentrate & 0.640 & 173.56 & 0.5650 & 25.0 & 16.4 \\
\hline Reagent -404 concentrate & 0.350 & 136.79 & 0.3600 & 16.0 & 16.4 \\
\hline Table concentrate & 2.800 & 58.34 & 0.0610 & 17.8 & 2.25 \\
\hline Tailing & 0.070 & 12.30 & 0.0335 & 2.05 & 3.70 \\
\hline
\end{tabular}




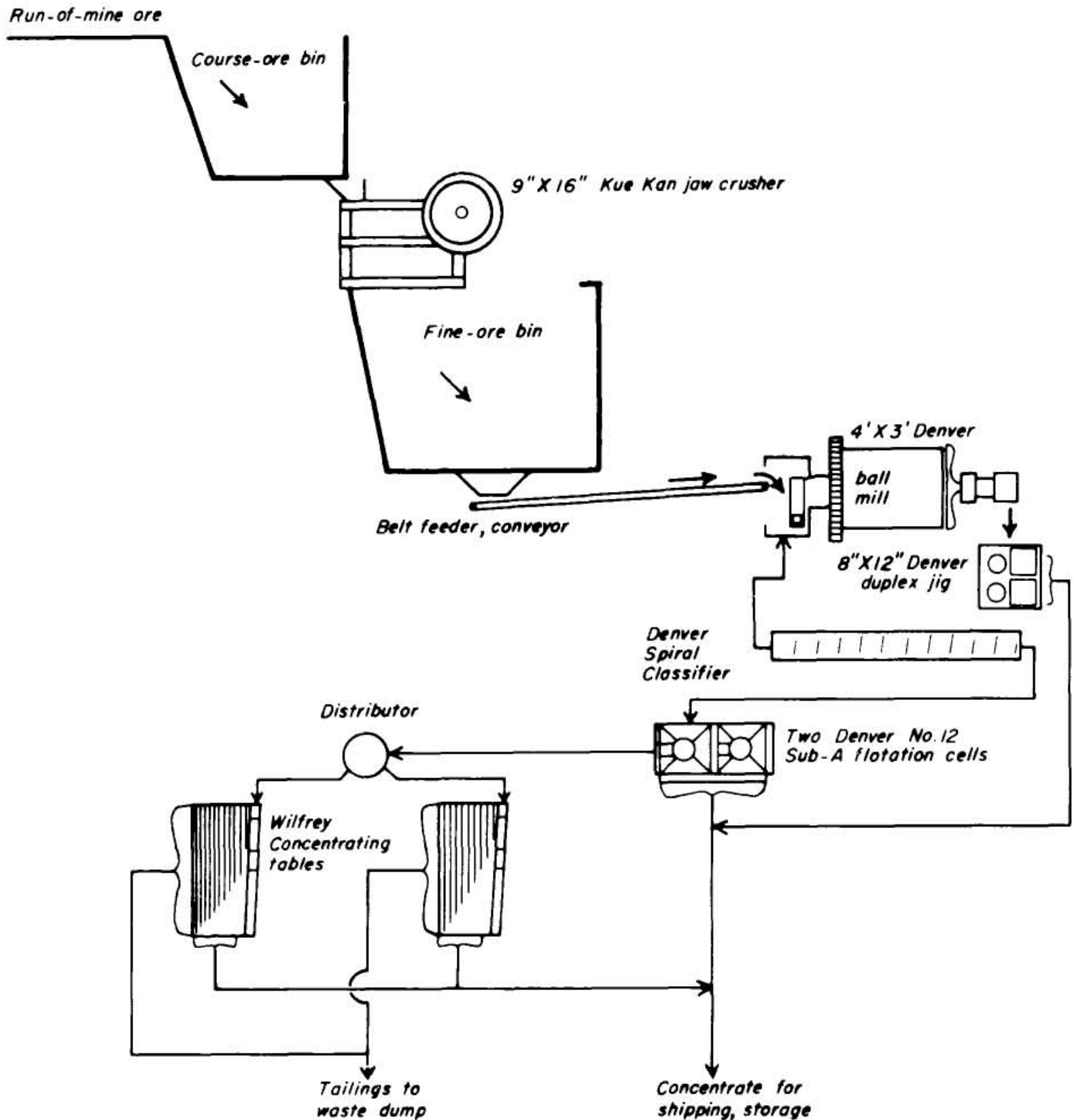

FIGURE 1 - Flow sheet, Alaska Mining \& Milling Co. concentrator

by X-ray diffraction. No other sulphide minerals were identified, and no silver mineral was identified. The gangue mineral is principally quartz. Metallic gold was identified in a panned concentrate and retained on a 100 -mesh screen prior to chemical analysis. Because there appears to be a ratio of $10-16$ ounces of silver for each percent of lead that is present, the silver or silver mineral is assumed to occur within the galena.

\section{FLOTATION AND GRINDING}

The mineral assemblage is such that it should be possible to separate the sulphide minerals by selective flotation and to recover the gold by flotation. Galena can be depressed by a dichromate, sphalerite by cyanide or zinc sulphate, and pyrite by cyanide and $\mathrm{pH}$ control. The flow sheets of the Bunker Hill (Idaho), Leadville (Colorado), Pacococha 
(Peru), and Sullivan (British Columbia) concentrators [by Sather, 1961; Crowell 1970; and Daman (undated), and an editorial in Engineering Journal, 1973] indicated a sequence in which the galena could be floated and the sphalerite depressed by cyanide and zinc sulphate. The sphalerite would be activated by copper sulphate. Glembotskii (1963) indicated that pyrite will be depressed at a $\mathrm{pH}$ of 8 or higher, and that it can be activated for flotation by adding sulphuric acid, which will lower the $\mathrm{pH}$ to 7 or less.

Before attempting a flotation test, a grinding test and three screen analyses were made. The analyses (fig. 2) indicate that a 20-minute grind would be required to reduce particle size to -65 mesh for flotation. The time required to grind to -200 mesh material suggests that the ore could be classified as 'medium' for determining ball-mill capacity. Microscopic examination of the $-65+100$ mesh grains indicated a separation of sulphide from gangue at -65 mesh.

\section{FLOTATION TESTS}

Five flotation tests were completed on the Kantishna ores. Because xanthates are stronger collectors than dithiophosphates, sodium isopropyl xanthate, sold by Dow Chemical as Z-11, was chosen as a collector. Dow Froth 250 was selected as a frother. Table 2 shows the result of the first test, where the xanthate was fed at a starvation rate to inhibit zinc flotation. The results indicate that nearly equal amounts of lead and zinc were present in the lead concentrate and that half of the lead carried over to the zinc concentrate. A high-grade lead-silver concentrate was produced.

Inasmuch as the collecting agent had been starved, another flotation test was made in which sodium isopropyl xanthate was incrementally added to determine the optimum amount; table 3 and figure 3 indicate the results. Cyanide was added to provide additional depression of sphalerite. Figure 3 shows that silver recovery follows lead recovery and that an increase in $\mathrm{Z}-11$ caused more zinc to be recovered. The total recovery of gold, silver, lead, and zinc was above $90 \%$.

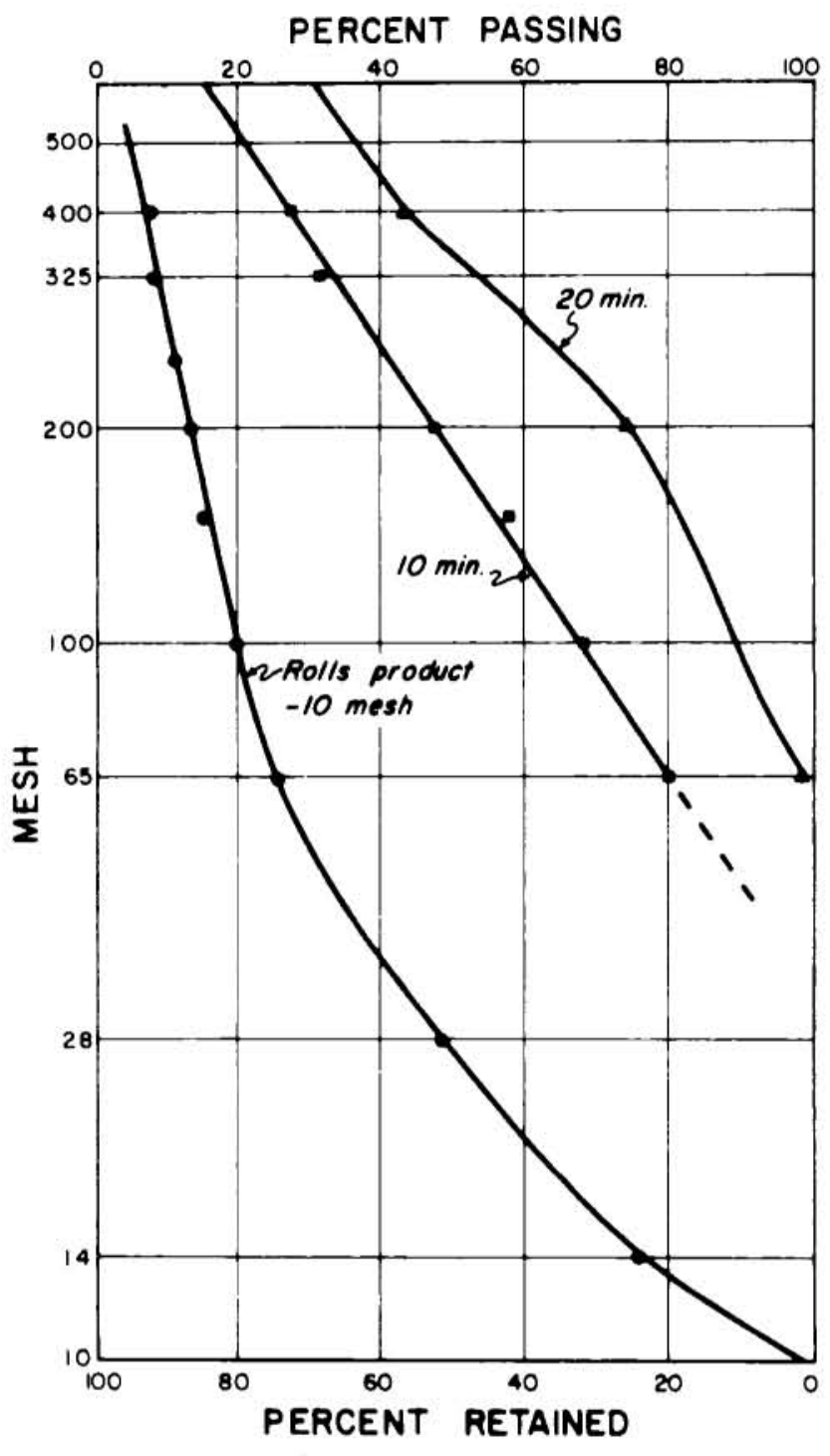

FIGURE 2 - Grinding test by sieve analysis

TABLE 2. Flotation test 1

\begin{tabular}{|c|c|c|c|c|c|c|c|}
\hline \multicolumn{8}{|c|}{ Place of reagent addition and amount ( $1 \mathrm{~b} / \mathrm{ton})$} \\
\hline & $\mathrm{pH}$ & Lime & $\mathrm{ZnSO}_{4}$ & $\mathrm{Z}-11$ & DF -250 & $\mathrm{CuSO}_{4}$ & $\mathrm{H}_{2} \mathrm{SO}_{4}$ \\
\hline Lead concentrate & $\overline{9.0}$ & $\bar{x}$ & $\overline{0.2}$ & $\overline{0.04}$ & $\overline{0.10}$ & - & - \\
\hline Zinc concentrate & 10.2 & $\mathrm{x}$ & - & 0.02 & 0.05 & 0.4 & - \\
\hline Pyrite concentrate & 7.2 & - & - & 0.10 & - & - & $\mathrm{x}$ \\
\hline \multicolumn{8}{|l|}{ Analyses } \\
\hline & $\mathrm{Pb}(\%)$ & $\mathrm{Zn}$ & \multicolumn{2}{|r|}{$\mathrm{Cu}(\%)$} & $\mathrm{Ag}(\mathrm{oz} / \mathrm{pt})$ & \multicolumn{2}{|c|}{$\mathrm{Au}(\mathrm{oz} / \mathrm{pt})$} \\
\hline Heads & 5.86 & & \multicolumn{2}{|r|}{0.17} & 49.8 & \multicolumn{2}{|c|}{0.18} \\
\hline Lead concentrate & 17.30 & 17. & \multicolumn{2}{|r|}{0.81} & 342.2 & \multicolumn{2}{|c|}{0.77} \\
\hline Zinc concentrate & 18.00 & 40. & \multicolumn{2}{|r|}{0.21} & 34.0 & \multicolumn{2}{|c|}{0.25} \\
\hline Pyrite concentrate & 4.02 & & \multicolumn{2}{|r|}{0.11} & 2.4 & \multicolumn{2}{|c|}{0.40} \\
\hline Tailing & L. 23 & & \multicolumn{2}{|r|}{0.05} & 3.7 & \multicolumn{2}{|c|}{0.03} \\
\hline
\end{tabular}


TABLE 2 - continued

Distribution (\%)

Heads

Lead concentrate

Zinc concentrate

Pyrite concentrate

Tailing

$\begin{array}{rr}\frac{\text { Wt. }}{100.00} & \frac{\mathrm{Pb}}{100.00} \\ 12.36 & 36.47 \\ 14.56 & 44.70 \\ 7.33 & 5.04 \\ 65.76 & 13.79\end{array}$

$\frac{\mathrm{Zn}}{100.00}$
27.71
59.36
5.56
7.73

$\frac{\mathrm{Cu}}{100.00}$

60.67

18. 50

4.93

15. 90
$\mathrm{Au}$

$\overline{100.00}$

$\overline{100.00}$

84.82

52.70

9.93

20.15

0.36

4.89

16.23

10.92

$\mathrm{x}$ - Reagents used in unmeasured quantities until required pH was obtained.

TABLE 3. Flolation test 2

Place of reagent addition and amount ( $1 \mathrm{~b} / \mathrm{ton}$ )

Ba.1 mill

Lead concentrate 1

Lead concentrate 2

Lead concentrate 3

Lead concentrate 4

Zinc concentrate

Pyrite concentrate

Analyses

Head:

lead concentrate 1

Lead concentrate 2

Lead concentrate 3

Lead concentrate 4

Zinc concentrate

Pyrite concentrate

Tailing

\section{Distribution (\%)}

Heads

Lead concentrate 1

l.ead concentrate 2

Lead concentrate 3

Lead concentrate 4

Zinc concentrate

Pyrite concentrate

Tailing

$\frac{\mathrm{pH}}{-} \quad \frac{\mathrm{NaCN}}{0.1} \quad \frac{\text { Lime }}{\mathrm{x}} \quad \mathrm{Zn}$

9.5

$-$

$-$

7. 7

10.5

7. 2

\begin{tabular}{r}
$\mathrm{Pb}(\%)$ \\
\hline 3.45 \\
26.50 \\
13.50 \\
5.30 \\
3.90 \\
1.50 \\
1.30 \\
0.17
\end{tabular}

$\frac{\mathrm{Zn} \cdot(\%)}{8.75}$
13.50
25.00
37.00
42.00
42.50
2.00
1.02

\begin{tabular}{c} 
Cu (\%) \\
\hline 0.19 \\
1.04 \\
0.93 \\
0.41 \\
0.24 \\
0.17 \\
0.15 \\
0.06
\end{tabular}

$\frac{Z-11}{-}$

$\frac{\mathrm{DF}-250}{-}$

\begin{tabular}{cc}
$\mathrm{CuSO}_{4}$ & $\frac{\mathrm{H}_{2} \mathrm{SO}_{4}}{-}$ \\
\cline { 1 - 1 } & - \\
- & - \\
- & - \\
- & - \\
0.4 & - \\
- & - \\
& $x$
\end{tabular}

0.2

0.04

0.04

- 0.04

- 0.04

- 0.02

\begin{tabular}{l}
$-\quad 0.08$ \\
\hline
\end{tabular}

0.1

$-$

-

0.05

$-$

\begin{tabular}{c}
$\mathrm{Ag}(\mathrm{oz} / \mathrm{pt})$ \\
\hline 23.1 \\
379.2 \\
234.7 \\
87.5 \\
58.9 \\
26.2 \\
5.0 \\
1.9
\end{tabular}

\begin{tabular}{cl}
$\mathrm{Au}(\mathrm{oz} / \mathrm{pt})$ \\
\hline 0.14 \\
1.40 \\
0.61 \\
0.50 \\
0.15 \\
0.11 \\
0.11 \\
0.02
\end{tabular}

\begin{tabular}{rrr}
\multicolumn{1}{c}{ Wt. } & & \multicolumn{1}{c}{$\mathrm{Pb}$} \\
100.00 & & 100.0 \\
4.42 & & 48.4 \\
4.63 & & 25.9 \\
2.79 & & 6.1 \\
3.01 & & 4.9 \\
8.84 & & 5.1 \\
9.33 & & 5.0 \\
66.98 & & 4.6
\end{tabular}

\begin{tabular}{r}
\multicolumn{1}{c}{$\mathrm{cu}$} \\
\hline 100.0 \\
34.4 \\
22.3 \\
6.0 \\
3.6 \\
7.8 \\
7.2 \\
1.8 .7
\end{tabular}
$\frac{\mathrm{Ag}}{100.0}$
47.4
30.8

$\frac{\mathrm{Au}}{100.0}$

43.7

13.5

12.0

14.7

43.2

2. 2

1.5

18.7
19.9

9.8

3.2

$\begin{array}{ll}5.0 & 3.2 \\ 6.6 & 6.8 \\ 1.3 & 7.2\end{array}$

$\begin{array}{ll}5.0 & 3.2 \\ 6.6 & 6.8 \\ 1.3 & 7.2\end{array}$

$1.8 \quad 9.4$

x- Reagents used in unmeasured quantities until required $\mathrm{pH}$ was obtained.

In a third flotation test, a selection of $0.1 \mathrm{lb}$ per pound of Z-11 was made and the amount of cyanide was increased to 1.0 pound per ton. Table 4 indicates that the lead concentrate still had a nearly equal amount of zinc and that the zinc concentrate was less than $50 \%$ zinc. A fourth test (table 5 ) was made for a bulk flotation product.
A final flotation test was made in which a bulk sulphide was produced, and then ground for an additional 20 minutes (table 6). Again, the silver shows strong correlation with the lead. The amount of zinc increased in the lead concentrate. The zinc concentrate is near the acceptable level. 
MINERAL PREPARATION OF ORES FROM FRIDAY CREEK,

KANTISHNA MINING DISTRICT, ALASKA

TABLE 4. Flotation test 3

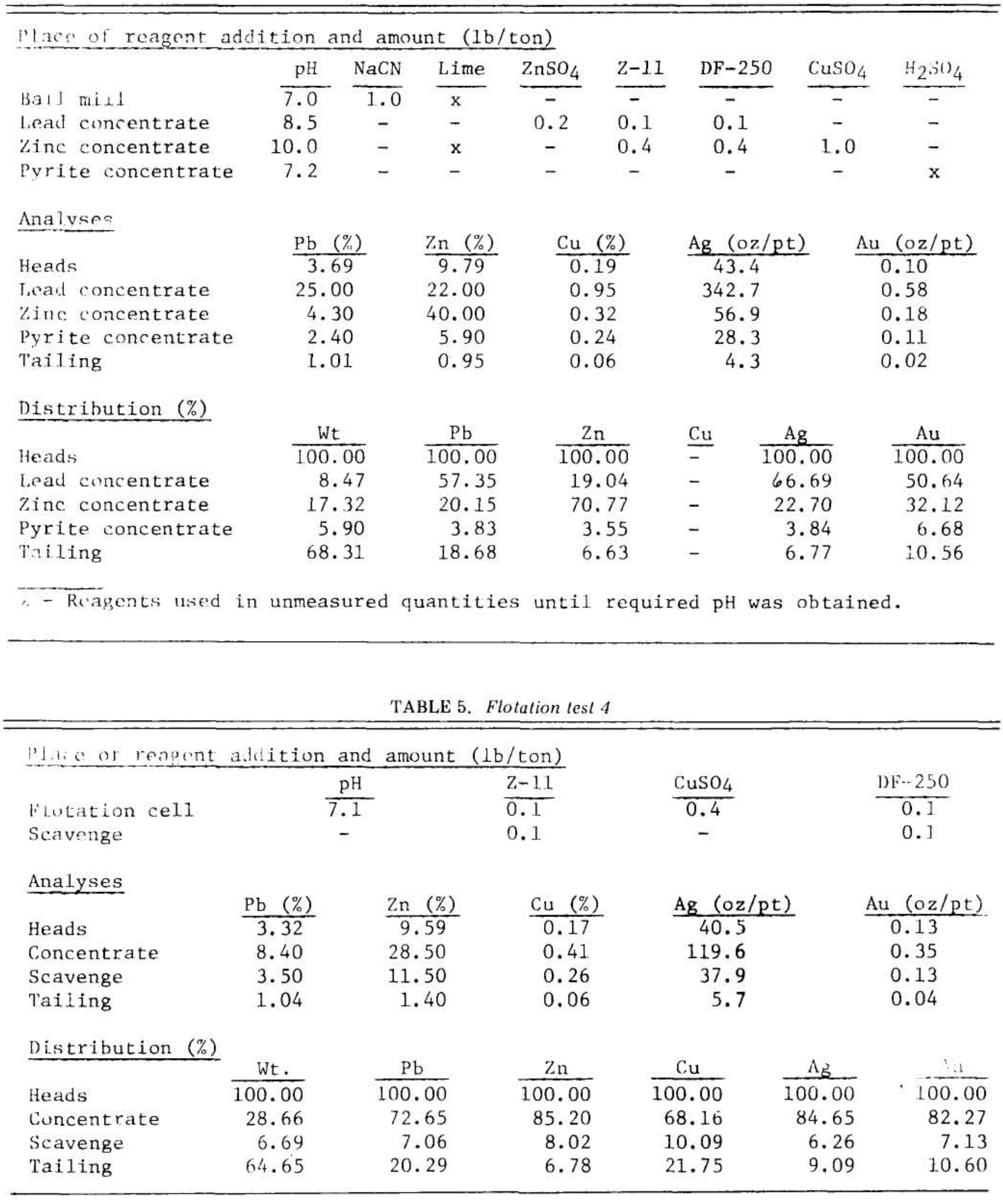




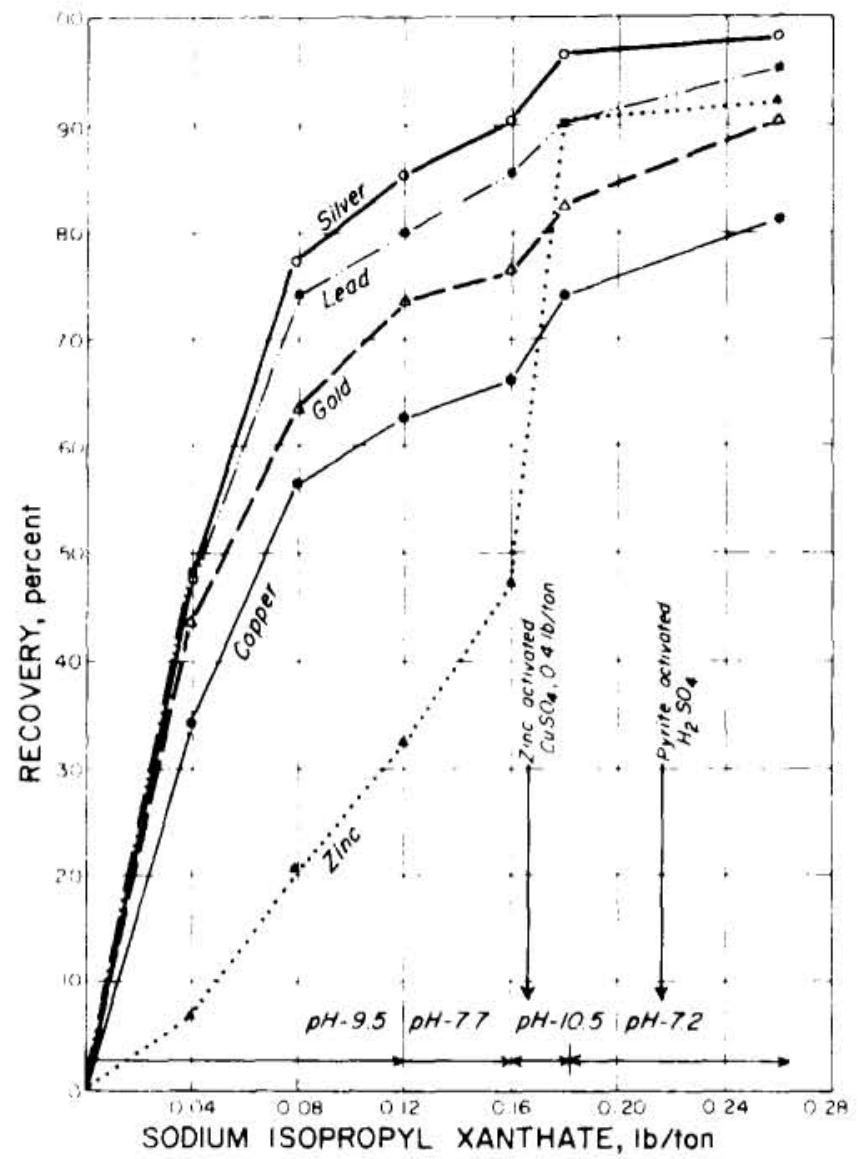

FIGIIRE 3 - Kantishna ore, recovery-reagent curves for sodium isopropyl xanthate

'The pyrite concentrate as a percentage of the total product increased from the $6-9 \%$ of the previous tests to $15 \%$ of the total weight; also, $70 \%$ of the total gold reported with the pyrite in this test. In the chemical analyses, about $90 \%$ of the gold was retained on a 100 -mesh screen and weighed as a metallic for inclusion in the analysis of gold. This identification of metallic gold indicates the gold could be recovered by amalgamation.

The 20 minutes of additional grinding produced a bulk product containing the following size fractions: $1 \%,+200$ mesh; 29\%, 200/400 mesh; and 70\%, -400 mesh. These compare favorably with the initial feed to the flotation circuit at the Sullivan concentrator $(84 \%,-200$ mesh). Even a finer grind, perhaps to -600 mesh, would be required to produce a satisfactory lead-zinc separation.

Such a fine grind produces special problems in flotation. It may be possible to make a satisfactory zinc concentrate, however, and still recover $76 \%$ of the silver in a lead concentrate with a concentrating ratio of 9 to 1 (table 6). All five flotation tests indicate that more than $90 \%$ of the silver could be recovered. The bulk sulphide concentrate ratio is about 2 to 1 . Fine grinding will be required to separate the sulphide minerals.

\section{POLISHED SECTIONS}

Because galena and sphalerite did not separate easily in the flotation tests, it can be assumed they were not liberated in the grinding. Photomicrographs of the concentrates (fig. 4) show the complex intergrowth of the minerals. Individual sulphide grains are generally less than 37 microns in size ( 400 mesh) which requires a grind of about 15 microns to effectively separate the sulphide mineral.

\section{MILL CAPACITY}

The capacity of machines in the circuit is determined by many variables, including the hardness of ore, the grind required for liberation, and the specific gravity. In the Kantishna mill (fig. 1) the crusher should have a capacity of 6 tons per hour or 144 tons per day, from run-of-mine ore to $-1 / 2$ inch. This would permit crushing on one shift. The ball mill is the controlling factor in determining overall capacity. A 4 - by 3 -foot mill will grind an ore of medium hardness to -65 mesh at 35 tons per day if the feed is $-1 / 2$ inch. But if a -100 mesh grind is required, the production of the mill will drop to 22.5 tons, as computed by the Denver Equipment Company's ball-mill slide rule.

The 8 - by 12 -inch Denver duplex jig in closed circuit with the ball mill and classifier would have a capacity of 15 to 70 tons per day. The results of table 1 indicated a good, marketable product from the jig. The classifier will control the size of feed to the flotation cells. A 16-inch high-weir simplex classifier is of adequate size (figures 5 and 6); the feed has a specific gravity of 3.46 ; therefore, the classifier would operate at about $137^{\circ}$ of capacity.

The two No. 12 flotation cells in the Kantishna mill are not considered adequate. The use of only two cells can cause a short-circuiting of feed and does not permit sufficient retention time.

The two concentrating tables are adequate; each table should be able to treat 25 tons per day. As shown in table 1 , the table product recovered the gold in a concentrate high in lead and low in zinc.

\section{MARKETING}

The ideal separation product from these ores would have been a high-lead concentrate containing the precious metals, a zinc concentrate assaying more than $50 \%$ zinc, and a pyrite product that could be discarded. Unfortunately, these products were not obtainable by the selective flotation tests.

Trial results indicate the marketing possibilities should be investigated further; the tradeoffs with respect to smelters are numerous. For example, zinc smelters have the highest smelting rate, do not pay for lead, and only pay about $60 \%$ of the value of precious metals. A lead smelter seemingly offers the best payment for lead and precious metals, but may penalize for zinc. Copper smelters 

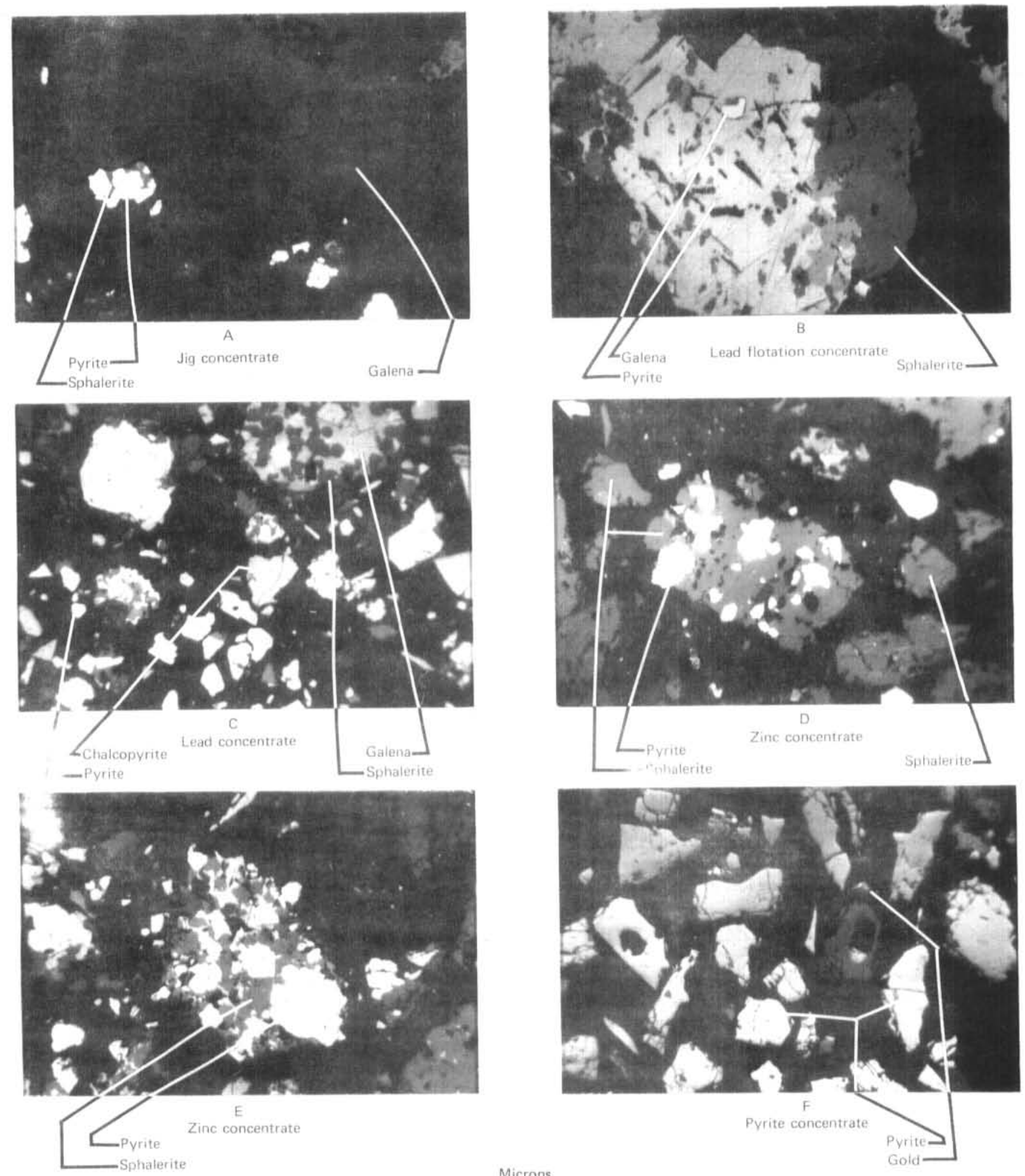

Microns

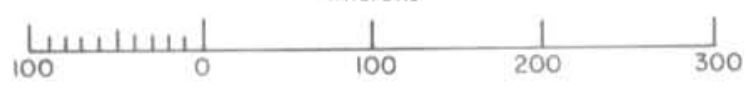

FIGURE 4. Photomicrographs of Kantishna ore concentrates. A, Coarse-grained galena with inclusions of pyrite and sphalerite in the jig concentrate. B, A grain of galena with attachment of sphalerite. C, Intergrowth of galena and sphalerite, with clean grain of chalcopyrite. D, E, Fine intergrowths of pyrite and sphalerite. F, Clean pyrite grains and a gold particle. 
Place of reagent addition and amount ( $1 \mathrm{~b} / \mathrm{ton})$ - bulk flotation

Float cells

$$
\frac{\mathrm{pH}}{7.1} \quad \frac{\mathrm{Z}-11}{0.1} \quad \frac{\mathrm{DF}-250}{0.2}
$$

Reground sulfide

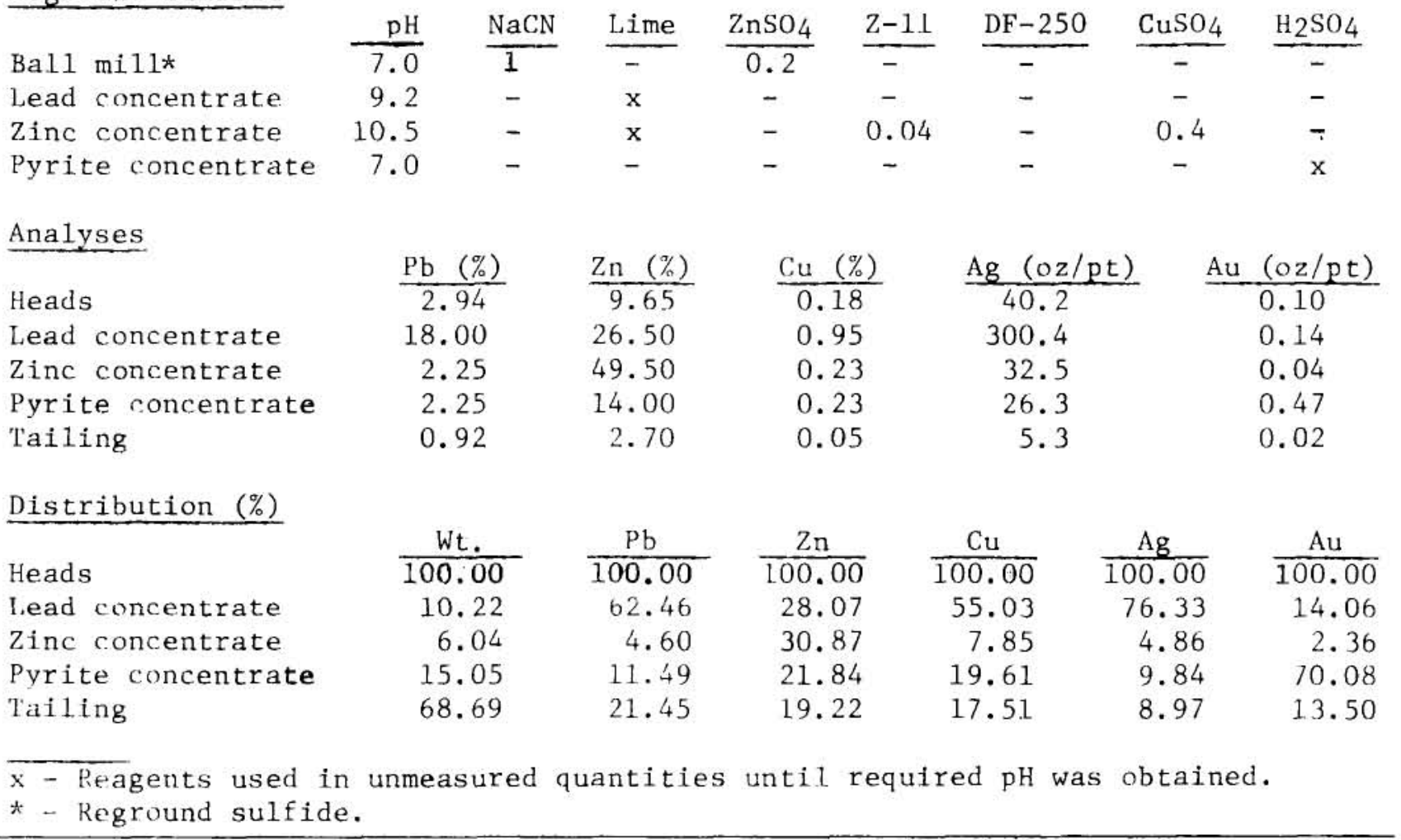

have the lowest smelting rate, but would only pay for gold and silver, and would take the ore only if the silica (quartz) content was high enough to provide silica as a flux. (Selling the crude ore as a flux would recover precious metals that would otherwise be lost in tailings.)

\section{REVIEW AND RECOMMENDATION}

Recovering gold and silver in a galena-sphalerite-pyrite separation is a complex problem. The first factor to consider is the selection and combination of the proper chemical collectors. Sodium isopropyl xanthate was used in the tests because of its high collection power and low cost. When used in proper amounts, this reagent recovered over $90 \%$ of the gold-silver-lead and zinc. Nevertheless, experiments with other collectors should be tried.

Ethyl xanthate is a good reagent for lead and zinc flotation. Although xanthates are stronger collectors than dithiophosphates, the author recommends a test in which xanthate is used with a dithiophosphate such as Aerofloat 242 ; the latter chemical is selective toward galena, which appears to carry the silver. In tests 2 and 5 , over $60 \%$ of the lead and $75 \%$ of the silver was recovered in a 9-to-1 concentrate. In an area of high shipping costs, the economics of this concentrate should be closely examined.

Cyanides dissolve gold and lime depresses gold. The depressing effect of the lime on this ore is indicated by the free gold reporting in part with the pyrite. In the flotation of gold, high - and low-chain xanthates are often used in combination. Although the overall recovery of gold was good with Z-11, a combination of an ethyl xanthate and an isobutyl xanthate might float more of the gold in the lead concentrate. On the basis of available knowledge, however, it is probably best to continue depressing the gold with lime and recovering it with the pyrite.

The flotation tests indicate that the grind selected was satisfactory for the liberation of the sulphide from the gangue, but not fine enough to permit separation of the different sulphide minerals. In regrinding the sulphides, a zinc concentrate was produced, but it only contained $30.87 \%$ of the total zinc.

In reviewing the products from the plant (table 1), the jig, flotation, and table produced satisfactory concentrates. However, the recovery of silver, lead, and zinc was poor. 


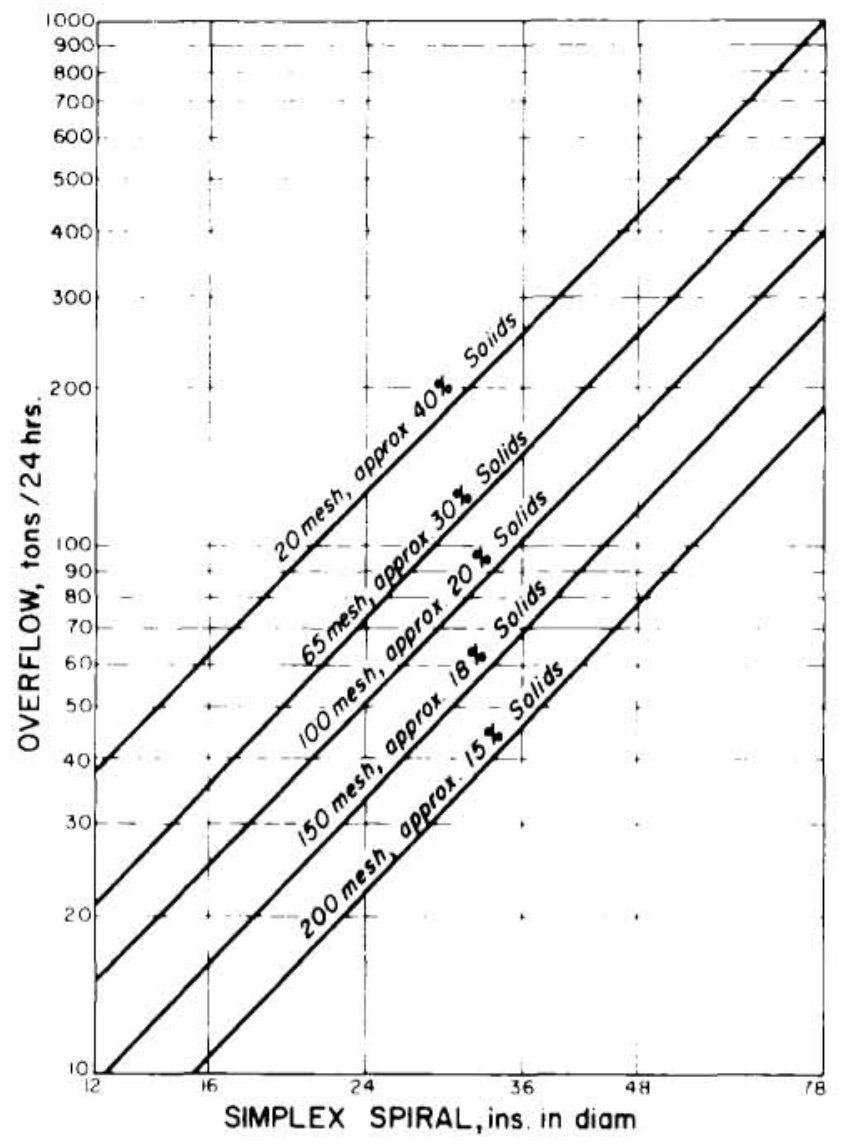

FIGURE 5 - High-weir simplex spiral classifier

Therefore, this report recommends:

1. Continuing research on the best methods of recovery.

2. Replacing the two-cell No. 12 flotation machine with a six-cell No. 12 flotation machine which will permit a rougher, a scavenger, and a cleaner circuit.

3 . Setting the density of the overflow from the classifier to provide a -65 mesh feed to the flotation cells, and continuing the recovery by the jig.

4. Replacing the dithiophosphate Aerofloat-33 or -404 with a xanthate (Dow Z-11 or Cyanamide 343).

5. Trying combinations of Cyanamide 343 and 242 then a combination of Dow Z-3 or Z-4 with Dow Z-14.

6. Depressing the pyrite by operating the flotation circuit at a $\mathrm{pH}$ of 9-10.

7. Recovering the gold and pyrite on the tables.

8. Experimenting to see if gold can be recovered by amalgamatation.

9. Keeping the jig, flotation, and table products separate for sale.

10. Experimenting by regrinding the flotation product.

11. Investigating the best marketing method.

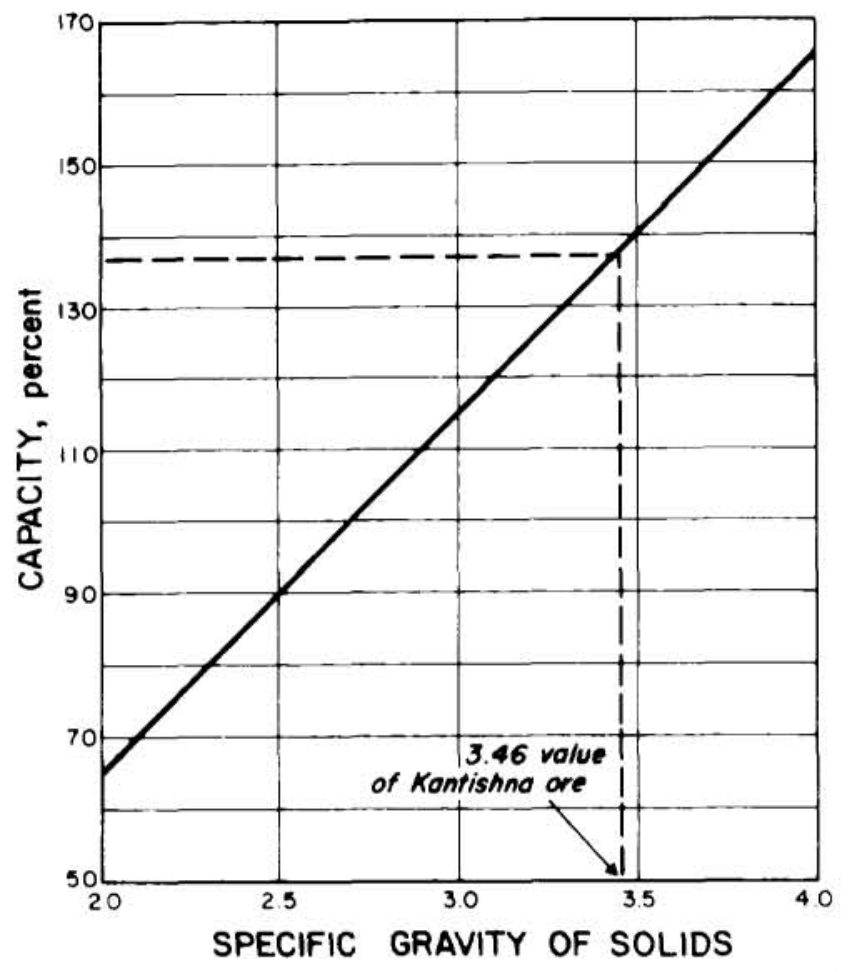

FIGURE 6 - Correction factor of solids $(2.7=100 \%)$

\section{REFERENCES}

Crowell, D.E., 1972, Design of the Leadville Concentrator: Mining Engineering, November, p. 28-34.

Daman, A.C. Jr., Sindicato Minero Pacocoha, S.A., Denver Equipment Company. Bulletin No. M4-B110.

Engineering and Mining Journal, 1973, The Sullivan: Heart of Cominco's Mining Empire: September, p. 108114.

Glembotskii, V.A. and others, 1963, Flotation: Primary sources printed by Monument Press, New York City, $620 \mathrm{p}$.

Sather, N.J., 1961, Bunker Hill's Concentrator: Mining Engineering, June, p. 573-577. 